lys for den enkelte, er en sympati med det fælles vel nødvendig for at sikre opbakning bag samfundet afgørende institutioner (sml. pp. 32-50).

Mens bogens udvalg af tekster, som antydet ved Smith-citatet, ofte synes at understøtte grundtemaet, som antydet af introduktionen, godt, er det ikke konsekvent tilfældet. Således består Hume-udvalget af en række brede essays om "borgerlig frihed", "kunstarternes og videnskabernes opståen og udvikling" og "om handel". Det er rigtigt, at en række af den skotske oplysnings grundantagelser afspejles her (p. 10), men givet angivelsen af grundtemaet, savner man et uddrag af Humes retfærdighedsteori. Med hensyn til den sidste, eller læsningen af denne, vil jeg tillade mig at nævne en enkelt skønhedsplet $i$ introduktionen. Det fremgår, at Hume med hensynet til spørgsmålet om politisk forpligtigelse (i kraft af hvad er borgerne forpligtigede $i$ forhold til staten?) peger på "samtykke" (consent) og samtykke modsættes ideen om en kontrakt (pp. 47-49). Det er meget misvisende. Hume er en navnkundig kritiker af ideen om consent eller samtykke (se mest oplagt essayet "of the original contract"), og samtykke/consent forstår han synonymt med kontrakt. Frem for en bevidst og frivillig handling som baggrund for politisk forpligtigelse peger Hume på den åbenlyse interessevaretagelse eller nytte ved et statsapparat (sml. p. 48).
Soren Flinch Midtgaard, Lektor, Institut for Statskundskab

\section{Oplysning versus kulturalisme}

Jens-Martin Eriksen \& Frederik Stjernfelt: Adskillelsens politik. Multikulturalisme - ideologi og virkelighed, Lindhardt \& Ringhof 2008, 496 sider, 299 kr.

Denne bog er af en række forskellige årsager svær at anmelde. For det første er det en bog sammensat af fem meget forskellige dele og meget forskellige emner, fx multikulturalisme, islam, ytringsfrihed, menneskerettigheder, retsstat, demokrati, nationalisme m.m. hvis forhold ikke altid er helt klart. For det andet er det, som dagspressens anmeldelser har vist, en bog, der i sin polemik fremprovokerer modpolemik og det på en måde der gør det svært at skelne ens faglige og personlige bedømmelse af bogens indhold. $\mathrm{Og}$ endelig er det for det tredje en bog, der for denne anmelder har det særegne ved sig, at jeg er enig i stort set alle tekstens grundargumenter men alligevel ganske uenig med selve teksten. Dette er derfor en anmeldelse, der tilstræber saglighed men som samtidig vil prøve at undersøge, hvorfor bogen både udfordrer men ikke helt overbeviser mig - og hvorfor den nogle steder irriterer mig.

Bogens tema er multikulturalisme, eller rettere er det politiseringen af kultur, hvor forfatterne meget rigtigt observerer, at kulturalisme behand- 
ler kultur, som racismen behandler biologi, nemlig som skæbne. Kulturalisme er "den opfattelse at folk er helt igennem determineret af deres kultur og er ude af stand til at overskride den. Og at det følgelig gælder om at hævde kulturens rettigheder over for individerne" (s. 14). Ét men kun ét af kulturalismens udtryk er multikulturalisme, hvor ambitionen er at fremme sameksistensen mellem autonome kulturer ved at lovsikre kulturernes indre liv, et andet udtryk er den aktuelle nationalisme, hvor ambitionen er at sikre én homogen kulturs dominans eller eneret.

Det synes åbenlyst rigtigt, at udtømningen af de politiske ideologier har fremmet genkomsten af 'hårde' orienteringsmarkører som religion og kultur, der forstås som forandringsresistente og totale meningsgivere, der i stadigt mindre grad tillader kritik af sin egen partikularitet men som tværtimod kræver respekt og ærbødighed fra dem, der ikke tilhører religionen eller kulturen, heraf den krænkelseskultur, som forfatterne først og fremmest lokaliserer i det religiøse og $i$ avis-kommentarer mener de tilmed, at den stammer fra muslimske aktører og derfra har bredt sig til andre, hvilket virker helt åbenlyst forkert eller i bedste fald kun delvist rigtigt. Rigtigere er nok at se de aktuelle religiøse og kulturelle overfølsomheder som udtryk for en generel og global vending efter de politiske ideologiers udmattelse. Forfatterne har en vis tendens til at ekstrapolere fra ethvert udtryk, der kunne tolkes kulturalistisk, til at det er ren kulturalisme, en total opgivelse af oplysningsidealer, et knæfald for islamismen osv. Der synes her at være en måske polemisk virksom kraft, der til tider skygger for, at de fleste argumenter og positioner dels er indlejret $\mathrm{i}$ fortolkningskampe og dels er mere praktisk anlagt end filosofisk funderet, altså at de har en aktuel og lokal problemstilling for øje snarere end at være udtryk for en hel filosofi, i dette tilfælde kulturalisme. At man selv er optaget af noget (som forfatterne vil kritisere), gør ikke at alle andre også er optaget og indfanget af det samme.

Forfatterne benytter sig af en velkendt argumentatorisk figur, hvor to ekstreme og dubiøse positioner, venstre/multikulturalisme og højre/ monokulturalisme, står uforsonligt overfor hinanden samtidig med at de i egentlig forstand er udtryk for samme tendens, her kulturalisme, samtidig med at forfatterne står om ikke i midten så ovenover denne strid, hvorfra de lader ironi, kritik og fordømmelse regne ned over de vildledte. Der er en vis tendens til, at alle andre er kulturalister: alle på venstrefløjen er multikulturalister i den hårde forstand, alle på højrefløjen er monokulturalister $i$ den hårde forstand, og stort set alle muslimer er kulturalister i enhver forstand. Bogen er dog ikke så frigjort fra venstrehøjrestriden som den først tager sig ud. Den står klart til venstre, hvilket kan ses af, at det først og fremmest 
er venstrekulturalismen, der angribes. Det er vennernes svigt, der for alvor gør ondt, og derfor rettes den meste kritik imod det, som forfatterne ser som venstrefløjens opgivelse af arven fra oplysningstiden. Hvorvidt venstrefløjen rent faktisk har smidt oplysningstiden ud med badevandet forholder jeg mig tvivlende til, men at det er et opråb til venstrefløjen (i bredeste forstand) om ikke at lade sig forlede af kulturalismens sirenesang er ganske klart.

Bogen er i en vis forstand del af en trilogi, der starter med forfatternes to rejseskildringer fra ex-Jugoslavien: Hadets anatomi (anmeldt i SLAGMARK nr. 38/2003) samt Krigens scenografi, der viser én meget blodig konsekvens af en kulturalisme, der forstår sine omgivelser $i$ et sikkerheds- og fareperspektiv, idet sådanne diskurser tilsyneladende er manisk optaget af degeneration og forurening, faren for overskridelser, overløbere, forræderi, angreb og som betragter andre tilsvarende partikulariteter ikke som andre udgaver af religion eller kultur men som påtrængende trusler imod lige præcis deres religion eller kultur.

Bogen er opdelt i fem meget forskellige dele. Første del er en række interviews med intellektuelle i Malaysia samt en oprids af det, som forfatterne tolker som et gennemført og hårdt multikulturalistisk samfund. Anden del er en idéhistorisk udredning af kulturbegrebets genealogi fra den amerikanske antropologi umiddelbart efter anden verdenskrig til nutidens politiske filosofi. Tredje del er en semiotisk inspireret udlægning af Muhammed-krisen samt en samlæsning af Kurt Westergaards tegning af Muhammed med en Roald Als-tegning af Anders Fogh Rasmussen. Fjerde del er en længere række mindre interventioner i nutidens politiske debat om ytringsfrihed, kultur, oplysning og andre relaterede emner. Endelig er femte del et appendix bestående af en kronologisk oplistning af større og mindre udtryk for religiøst motiveret pres imod ytrings- og religionsfriheden fra 1970 'erne og frem til i dag.

Ingen anmeldelse kan yde bogen retfærdighed, da der er så mange emner, argumenter, påstande, veje at forfølge, så mange forskellige genrer: interview, genealogi, polemik, tegnanalyse, dokumentation, og der er en vedvarende splittethed $i$ bogen: handler den dybest set om islam (som kapitel 1 og appendikset mere end antyder) eller mest om vores forhold dertil? Denne anmeldelse vil overvejende bestå i nedslag i bogen, hvor jeg særligt fokuserer på de ting, der irriterer eller stikker ud, hvilket ikke er mange $i$ forhold til de ting, der begejstrer, inspirerer og oplyser. Anmeldelsen er derfor bevidst skæv. Den er som sagt ovenfor et forsøg på både at anmelde bogen og at forstå, hvorfor jeg ikke bare omfavner dens argument(ation), som jeg ellers er enig med.

Første del er JME's rejsedokumentar fra Malaysia og er bogens klart sva- 
geste. JME's sympatier og antipatier synes helt at blokere for ønsket om indsigt, og det viser sig i det stilistiske, hvor vi går fra overdrevent indfølende baggrundsbeskrivelser hos nogle af de interview-personer, som JME kan lide, her skabes identifikation, hvorimod der sættes en ganske anden, stacatto-agtig scene hos dem, JME ikke kan lide. Bogen ville have stået bedre uden disse overflødige 100 sider, der har relevans for dem, der interesserer sig for Malaysia men som ikke synes videre oplysende for det emne, der er bogens tema.

JME skriver s. 23, at "Malaysia forekommer mig at være et samfund, som har alt det, som vi i Europa endnu ikke er ankommet til", dvs. et gennemført multikulturelt samfund. Men der tager han vist fejl, for Europa er - om end i en svagere udgave - allerede kommet til Malaysia, nemlig til et samfund, der i stigende grad erklærer særrettigheder for majoritetskulturen. Malaysia er nemlig på ingen måde det gode eksempel på multikulturalismens genvordigheder, som JME og FS tror, idet der ikke her gives særrettigheder til diverse minoritetskulturer men derimod til majoritetskulturen. Og det er ikke multikulturalisme men måske nok hård kulturalisme. Så Malaysia virker ikke som den oplagte ramme at diskutere multikulturalisme med, og måske heller ikke islam, medmindre man da ønsker at komme væk fra forestillingen om, at der ikke findes noget sådan som islam slet og ret, men derimod en række lokalt kontingente, der hver tilbyder en særegen tolkning af, hvad islam er, i det malaysiske tilfælde en autoritær statsislam.

Anden del af FS er ganske anderledes lærd og er i realiteten en idéhistorisk udredning af ét af multikulturalismens intellektualistiske rødder i den amerikanske efterkrigstids-antropologi (s. 183 gøres denne til oprindelsen til kulturalismen, hvilket bidrager til forvirringen, for den er vel ikke en del af inspiration til monokulturalismen, hvis politiske udtryk den står i klar modsætning til?). En refleksion over andre rødder til multikulturalismen end de intellektualistiske - fx de lokale, praktiske problemløsninger - kunne have kvalificeret diskussionen, da det stiller spørgsmålet om ikke multikulturalismens eventuelle positive og negative konsekvenser først og fremmest stammer fra praktisk-pragmatisk politik og mindre fra indre modsigelser i det, vi kunne kalde den filosofiske multikulturalisme. Når det forbehold er taget, da er kapitlet en fremragende udredning og kritik af det, forfatterne kalder den hårde multikulturalisme. FS sporer dets opkomst til efterkrigstidens amerikanske antropologi og viser hvordan refleksionen over nazismens forbrydelser samt antropologiens egen race-hierarkiske forestillinger fremmer en naiv egalitarisme eller relativisme, der for enhver pris vil undgå moralske vurderinger, da det fejlagtigt (men i situationen forståeligt?) blev anset som endnu et ud- 
tryk for vestligt dominansudøvelse. Heraf udvikles et kulturbegreb, der hævder kulturens lukkethed, hvor den enkelte kultur bestemmer dens medlemmers meningshorisont, hvor kun medlemmer af kulturen kan forstå den, og hvor man ikke kan tillade sig at kritisere den kultur, man ikke kan forstå.

FS viser dernæst disse forestillingers videre liv i og udenfor antropologien. Det er en meget væsentlig genealogisk udredning, men der burde som sagt nok være medreflekteret andre inspirationer til den aktuelle kulturalisme. Til tider er den påståede forbindelse fra fortidens antropologi til nutidens multikulturalisme noget tynd, og der fokuseres til tider så tæt på enkeltformuleringer, der kan vises internt inkonsistente, at fx Will Kymlicka fremstår mere tåbelig end vel rimeligt er. Tilsvarende burde konteksten nok være taget mere alvorligt. FS holder sig ikke for god til kraftig ironisering $\mathrm{og}$ til en noget hård opstramning af konklusioner, og det altid til den samme side, nemlig til den side, hvor 'multikulturalisterne' fremstår som hårde og naive kulturalister. Flere steder fører harmen FS til at tiltro de kritiserede decideret idiotiske holdninger og tonen bliver lettere nedladende. Her kunne en refleksion over andet end den filosofiske multikulturalisme samt spørgsmålet om, hvorvidt der kan tænkes en ikke-kulturalistisk multikulturalisme, have styrket kapitlets afklaring af en vigtig men ofte overset del af det aktuelle kulturbegreb.
Kapitel 3 er en tegnanalyse af to karikaturer af hhv. Muhammed og Fogh, hvor FS glimrende dissekerer disse tegningers betydningsindhold. Her er masser at tænke over for alle dem, der ikke hurtigt besluttede sig for, at tegningerne enten var en nødvendig frihedshandling eller et uprovokeret angreb. Dog synes der her at være en igen noget opstrammet tolkning af, hvordan man med ret og rimelighed kan forholde sig til Jyllands-Postens tegninger og lidt for mange lidt for kontante påstande om, hvordan 'man', 'nogle' forholdt sig. Personligt kunne jeg have ønsket mig en supplerende undersøgelse af årsagerne til det, som forfatterne rigtigt og med velbegrundet frygt ser som en voksende krænkelses-kultur, hvor ofte selvudråbte repræsentanter for kulturer og religioner gør deres krav gældende med stigende skinger stemmeføring. Det kunne også have været med til at forklare, hvorfor FS måske kan have ret i sin tolkning af Kurt Westergaards tegning som ikkediskriminerende og samtidig forklare, hvorfor så mange så den netop sådan. Det er nok mere afgørende at fokusere mindre på spørgsmålet om nogen såkaldt objektiv krænkelse og mere på, hvorfor små fænomener som satiretegninger, forhæng $\mathrm{i}$ brusekabinen ved skolesvømning og meget andet ses af disse kulturforsvarere som angreb, hvorfor de betragter verden i krigs- og faretermer. Her kommer den 'neutrale' analyse af en objektiv måling af krænkelse til kort. 
Fjerde kapitel er en række mindre interventioner eller polemikker, hvor temaet er "dagens politiske hovedmodsætning [...] mellem oplysning og kulturalisme" (s. 276). Her er fremragende indslag om oplysning, sekularisme, kulturalisme - blandet med hvad jeg flere steder finder for lette og for udokumenterede påstande og tolkninger: s. 277 står der, at der findes "nominelle humanistiske forsvarere for islamistiske regler og dogmer i Danmark", det må vist bero på lidt for hurtig bevægelse fra tanke til tastatur; s. 278 gøres hele oppositionen tilsyneladende til venstrekulturalister; s. 347 mener forfatterne at vide, at andre er ligeglade med tegneren Kurt Westergaards sikkerhed, og der kunne fortsættes. Her gør forfatterne som den religiøse og nationalistiske kulturalisme: tolker i bedste fald deres modstandere som idioter, i værste fald som naivister, forrædere eller det der ligner; og afviser forestillingen om pragmatiske hensyn, der tværtimod beskrives som segregering, islamisering og andre lignende trusselstermer.

Det er vel nok her, min irritation over bogen stammer: dels er det sådan, som jeg skrev i starten, at det er vennernes fejltrin, der gør ondt, og her er det, hvad jeg anser som en vigtig kritik af kulturalismen, der så bliver brugt til at singularisere og monopolisere en række positioner, der kunne have været beskrevet anderledes, og som jeg personligt mener, burde have været anderledes - og som netop ikke følger automatisk af kritikken af kulturalismen, som forfatterne synes at mene; og dels er det disse mange overspilninger af pointer, uadresserede angreb, ironiseringer over andres idioti, stramning af modstanderes påstande til det uigenkendelige og det latterlige.

Det sidste er dog måske nok i sidste ende ikke så væsentligt. Polemik skal polemisere og provokere. Og det gør bogen. Man kan næppe lægge den fra sig uberørt; måske medmindre man tilhører dem, der er bogens angrebsfokus, hvor anmeldelserne tydeligt viste, at højrefløjen følte sig ramt og reagerede forudsigeligt vredt og helt i den til kedsomhed genkendelige refræn om at alle, der ikke en-til-en deler deres syn på islam som den vestlige verdens svøbe er tåber og forrædere, hvorimod venstrefløjen ikke har følt sig helt så ramt, hvilket jeg tolker som ulempen ved bogens polemiske tendens: polemikken gør dels bogen for skæv i forhold til noget af det, den vil kritisere, og dels er polemikken også undskyldningen for mange til ikke at engagere sig med og i det, der er det egentlige tema, nemlig kulturaliseringen af vores samfund og debat. $\mathrm{Og}$ det er synd. De fleste indlæg i kapitel fire er stærke kommentarer til vores tid, de bør tages meget alvorligt i debatten, da de er markante forsvar for en oplysningstradition, der for indeværende synes noget presset og med meget få egentlige og selvbevidste forsvarere.

Femte og sidste kapitel er et ap- 
pendix, der dokumenterer religiøst motiveret pres på ytrings- og religionsfriheden, og hvor der efter min vurdering er et lidt skævt fokus på islam. Hvis man læser Kristeligt Dagblad jævnligt vil man se, hvor mange også kristne anslag, der også er (hvoraf mange er med $i$ appendixet), og man vil se, at disse anslag ofte er ganske succesfulde $i$ at få lukket forestillinger, censureret forfattere etc. Der er et virkeligt og pågående pres imod frihedsrettighederne fra religionens og kulturens selvudnævinte talspersoner, og det er bogens styrke at bringe dette helt frem i debatten.

Som det fremgår af ovenstående er det en meget uhomogen bog, der måske nok vil for meget, $i$ den forstand at der ikke altid er tænkt nok over, hvordan de mange behandlede fænomener og sager hænger sammen, om de hænger sammen, om de er udtryk for én bagvedliggende problematik, eller hvad forholdet egentlig er. Bogen fremstår derfor ikke afklarende, hvis man går til den for at få en nøgle til at forstå de aktuelle udfordringer med hensyn til islam, kultur, ytringsfrihed, nationalisme, oplysning, integration m.m., som i debatten oftest blandes sammen i mere eller mindre uskønne blandinger. Her giver bogen ingen samlende forståelsesramme, hvilket synes at have været målet ved at tolke fænomenerne eller debatten om fænomenerne ind i kulturalismerammen. Til gengæld er bogen oplysende, provokerende og stimulerende, hvis man leder efter et indspark i debatten. Hvis man derimod ønsker at blive udfordret på sin egen position, så er dette bogen. For her meldes både kontant ud samtidig med at argumentationen føres på et højt og mestendels konsistent niveau. Hvis man ikke bare afviser projektet eller udfordringen, men tværtimod tager handsken op, så er der her både mange timer til læsning og endnu flere til eftertænksomhed.

Mikekel Thorup

\section{Metaphysik des Schwebens}

Vagn Andersen: Transformation Gottes - Abwandlungen des Begriffs des Unbedingten in der Moderne, Aarbus Universitetsforlag 2008, 324 sider, $398 \mathrm{kr}$.

En anmeldelse af denne disputats er en vanskelig sag. At der er vanskeligheder kan f.eks. gøres plausibelt ved henvisning til, at Vang Andersen selv har brugt 30 sider på at skrive et obligatorisk resume (på dansk). Jeg har aldrig før $i$ en disputats set så langt et resume, og det hører uden tvivl til de absolutte undtagelser. Det kunne have været interessant at se, hvad der var kommet ud af det, dersom V.A var blevet tvunget til at koge det ind til 3-5 siders normalpraksis.

Det lange resume har sikkert noget at gøre med flere forhold: for det første er argumentationen hele afhandlingen igennem på et uhyre højt niveau i stringens og problembevidsthed samtidig med at teori- 